\title{
METHODOLOGY OF TEACHING TECHNIQUES OF ACROBATIC EXERCISES
}

\author{
Pardayev B.P.
}

Lecturer, Scientific And Methodological Provision Of Physical Education And Sports Specialists Under The Ministry Of Physical Training And Sports Of The Republic Of Uzbekistan

\section{ABSTRACT}

The article discusses the benefits of teaching children basic acrobatic exercises. Different ways of engaging schoolchildren in acrobatics are presented with solid examples and rules. Also, this article provides effective and practical methods of instructing acrobatic activities at school. Along with this, the article supplies primary school PE instructors with an engaging acrobatic movements as well as games for schoolchildren who are in beginner level of doing acrobatics.

KEYWORDS: - Agility, speed, flexibility, basics of acrobatics, a sense of space, primary school students, acrobatic movements and games, physical education, physical activeness, physical qualities strength.

\section{INTRODUCTION}

In physical education classes in secondary schools, fitness work is the main means of gymnastic exercises.

Basic exercises in acrobatics, such as strength, agility, reaction speed, develop a sense of space, and simple cleansing and re-purification in the physical education program for young children in the training of the vestibular apparatus. Squeezes include balancing exercises, basic acrobatic exercises, dance steps, and exercises on gymnastic instruments.

Among the above tools, acrobatic exercises play an important role in the developmental skills of children in various movements, coordination development.

Various tasks can be solved through basic exercises in acrobatics. Beginner exercises in acrobatics allow for the physical preparation of coordination skills. Each lesson should include new acrobatic exercises. If the exercises are repeated, the lesson process will not be interesting and will not show the effect of acrobatic exercises. Even if each acrobatic exercise is mastered, it can be performed from different situations by changing the conditions of performance from different final parts. Analysis of the educational literature helps to select acrobatic exercises and determine the sequence of their training. In the selection and use of exercises, the presence of age-appropriate equipment for children implies the physical fitness of children.

It is advisable to use the algorithmic method recommended by Professor A.M. Shlyomin to teach basic exercise techniques in acrobatics. 
Simultaneously with the initial exercises in acrobatics, a structured program for young children is applied. Although beginner exercises in acrobatics are lacking in the elementary grades, they are considered to be a very effective tool if used in a variety of methodical movements. Courage in performing basic exercises in acrobatics improves self-control of the body and the spatial vestibular apparatus.

Beginner exercises in acrobatics play an important role in the development of children's physical qualities such as strength, speed, flexibility, agility.

Teaching basic exercises in acrobatics does not require sports equipment and facilities, only exercises can be taught if there are gymnastic mattresses. And every school has the opportunity to do that. It is advisable to conduct the initial exercises in acrobatics in a continuous and playful way in the form of mass teaching to increase the intensity of the lesson. Can be used in various action games, relays, crossing obstacles.

The structure and content of exercises for young children. In the program of young children, mainly guzhanak and various aghanas are held. These movement skills are used in all basic hardware departments. In addition, the following basic muscles are used.

\section{Methods of teaching basic exercises in acrobatics}

\begin{tabular}{|l|l|l|l|}
\hline \multicolumn{1}{|c|}{ Name of Exercise } & $\begin{array}{c}\text { Teaching } \\
\text { Method }\end{array}$ & $\begin{array}{c}\text { Conducting } \\
\text { Method }\end{array}$ \\
\hline \multicolumn{3}{|c|}{ G'ujanak } & \\
\hline $\begin{array}{l}\text { Execution technique. A bruise } \\
\text { is a bent position of the body. The } \\
\text { knees are brought close to the } \\
\text { shoulders, the hands are held below } \\
\text { the knees and the heels are paired. } \\
\text { Exercise is the main auxiliary } \\
\text { exercise. When teaching squats and } \\
\text { somersaults, the squats can be } \\
\text { performed in a sitting position, } \\
\text { squatting position, and lying on your }\end{array}$ & & \\
\hline
\end{tabular}




\begin{tabular}{|c|c|c|}
\hline back. & & \\
\hline $\begin{array}{l}\text { Training sequence. } \\
\text { 1. DhAt hands get up and } \\
\text { snuggle up. } \\
\text { 2. In the back-to-back position, } \\
\text { quickly sit with your legs folded. } \\
\text { 3. Hands up, lying on your } \\
\text { back. Being fast-paced. } \\
\text { 4. Lying on your back, sit } \\
\text { upright with your body up. } \\
\text { Errors: } \\
\text { 1. Head backward. } \\
\text { 2. The legs are very wide open. } \\
\text { 3. It is wrong to hold the feet } \\
\text { with the hands. } \\
\text { 4. The meeting at Gujanak is } \\
\text { incomplete }\end{array}$ & $\begin{array}{c}\text { Show, } \\
\text { verbal, holistic }\end{array}$ & $\begin{array}{l}\text { In the group } \\
\text { method }\end{array}$ \\
\hline
\end{tabular}




\begin{tabular}{|c|c|c|}
\hline $\begin{array}{l}\text { Execution technique. The } \\
\text { Infusion is that the body accelerates } \\
\text { in a series of movements without } \\
\text { passing behind the head. The } \\
\text { program can be performed on the } \\
\text { abdomen, waist, back and forth, } \\
\text { sideways and in a stretched position. }\end{array}$ & & \\
\hline $\begin{array}{l}\text { Training sequence. } \\
\text { 1. Return to the lumbar region } \\
\text { in a sitting position. } \\
\text { 2. Return from the reclining } \\
\text { position to the reclining position. } \\
\text { 2. Leaning back from the } \\
\text { climbing position to return to the } \\
\text { climbing position. } \\
\text { 3. Leaning back and forth } \\
\text { while lying on your stomach. } \\
\text { 4. Leaning back and forth } \\
\text { while lying on your stomach. } \\
\text { 5. Leaning on your knees while } \\
\text { leaning on your knees. }\end{array}$ & $\begin{array}{l}\text { Demonstra } \\
\text { tion, verbally, in } \\
\text { an integrated }\end{array}$ & $\begin{array}{l}\text { group } \\
\text { method }\end{array}$ \\
\hline Sequence of trai & ig to move forward & \\
\hline
\end{tabular}




\begin{tabular}{|c|c|c|}
\hline $\begin{array}{l}\text { Training sequence. } \\
\text { 1. Creating a nest in different } \\
\text { situations. } \\
\text { 2. Return to the starting } \\
\text { position by bending backwards while } \\
\text { sitting in a crouching position. } \\
\text { 3. From the supine position to } \\
\text { the supine position. } \\
\text { 4. Leaning forward in the } \\
\text { supine position. Advancing in the } \\
\text { supine position. } \\
\text { 1. Low depressions in the } \\
\text { legs. } \\
\text { 2. Lack of execution of the } \\
\text { gujarati. } \\
\text { 3. The position of the hands } \\
\text { is incorrect. } \\
4 . \text { Performed manually from } \\
\text { a squat position. }\end{array}$ & $\begin{array}{l}\text { Integral } \\
\text { presentation, } \\
\text { verbal }\end{array}$ & $\begin{array}{l}\text { performing } \\
\text { group mode }\end{array}$ \\
\hline \multicolumn{3}{|c|}{ Sequence of training to stand upright on shovels } \\
\hline $\begin{array}{l}\text { Training sequence. } \\
\text { 1. Standing on the shovels with } \\
\text { the legs bent backwards from the }\end{array}$ & $\begin{array}{l}\text { Integral } \\
\text { presentation, }\end{array}$ & $\begin{array}{l}\text { group } \\
\text { method }\end{array}$ \\
\hline
\end{tabular}




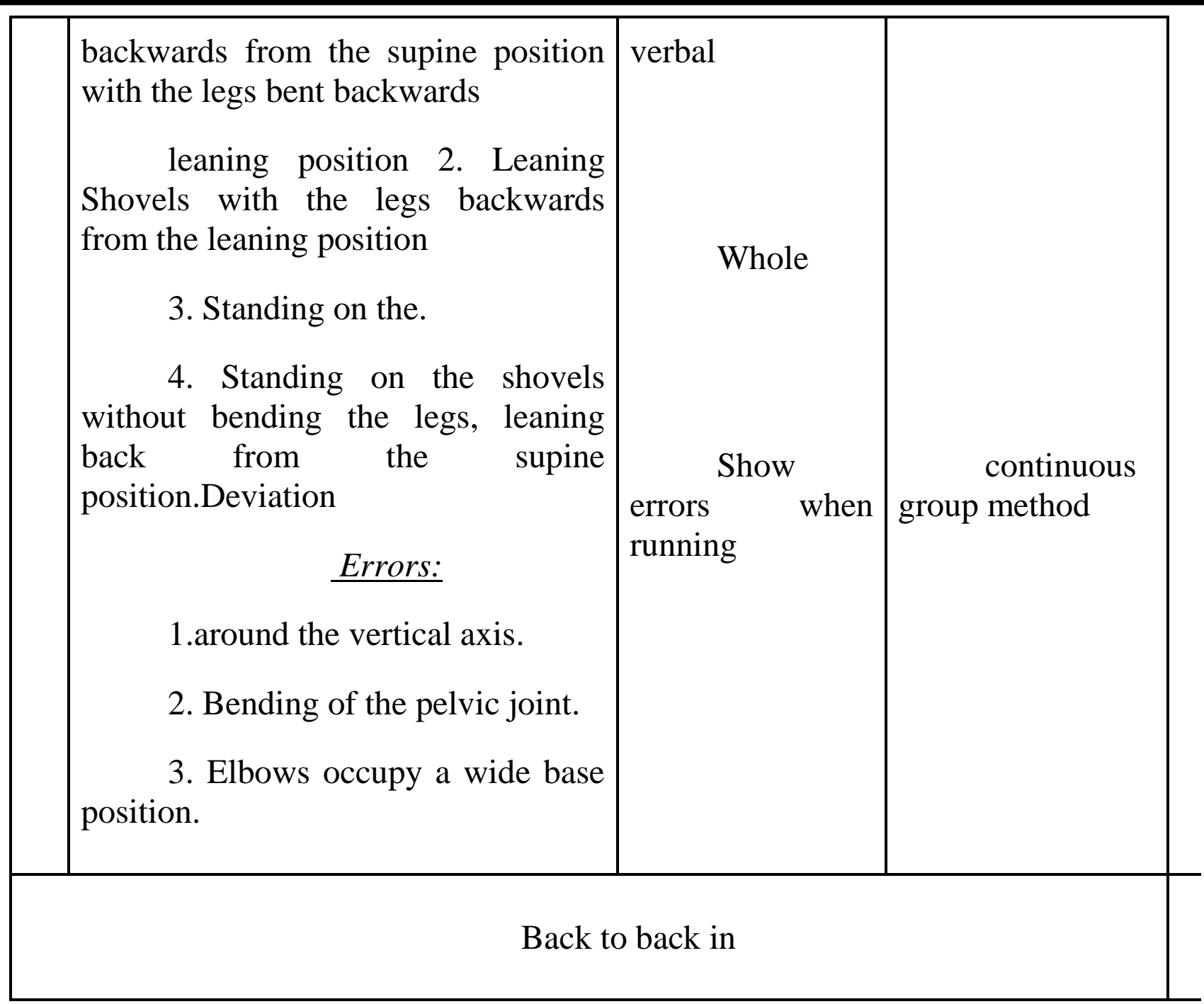




\begin{tabular}{|c|c|c|}
\hline $\begin{array}{l}\text { Training sequence. } \\
\text { 1. Going forward } \\
\text { 2. Leaning back from a squat } \\
\text { position. } \\
\text { 3. Leaning back over the } \\
\text { shoulder. } \\
\text { 4. climb back up from the top } \\
\text { of the hill. } \\
\text { 5. Back to back } \\
\text { Errors: } \\
\text { 1. Improper hand placement } \\
\text { 2. Properly perform the jerk } \\
\text { during deflection. } \\
\text { 3. Lack of strength to lean on } \\
\text { hands. } \\
\text { 4. Slow down. }\end{array}$ & $\begin{array}{l}\text { Show } \\
\text { errors when } \\
\text { running }\end{array}$ & $\begin{array}{l}\text { In } \\
\text { continuous group } \\
\text { mode }\end{array}$ \\
\hline
\end{tabular}

\section{THE MAIN PART}

Acrobatic exercises. Topic - backstroke, performance and improvement of the complex, development of physical qualities: bending the arms, stretching, lifting the legs from the hanging position

\section{Final PART}

Topic - distracting and calming exercises

Auxiliary exercises recommended for physical education classes show good results in mastering acrobatic exercises in the program.

Training program
Backstroke Techniques

1. Leaning on the legs in a narrow stretched position, shoulders slightly forward, forming a bulge;

2. Perform head-rolling and back-rolling;

3-4. The palms of the hands are placed on the ground behind the shoulders, turning the head;

5. Leaning up;

What does a student need to know in order to master backward growth?

1. Bend the shoulders forward while leaning forward.

2. While rolling back, you should bend the ankle and hold the shape until the arms touch the back 
CURRENT RESEARCH JOURNAL OF PEDAGOGICS 2(8): 101-109, August

2021 DOI: https://doi.org/10.37547/pedagogics-crjp-02-08-23

ISSN 2767-3278

(C)2021 Master Journals

Crossref do: 81 Google

Accepted $26^{\text {th }}$ August, 2021 \& Published 31 th August, 2021

of the shoulders, touching the neck mat.

3. The hands should be extended until the feet are placed on the mat.

What do you need to know? Quickly squat back, roll over and lean back on the shoulders with your hands.

It turned out that acrobatic exercises alone would not achieve a positive result if they were taught during a physical education class. A big help here is that complete and quality mastery of acrobatic exercises is possible only if homework is done. Through homework, the following educational tasks are solved:

children's movement activity increases;

strengthens the main muscles;

restores stature.

\section{Conclusion}

In conclusion, when teaching acrobatic exercises, it is necessary to use visual, word-by-word, whole-piece techniques. After demonstration and oral explanation, the children are done in practice. Mistakes and support exercises should be used in the execution process.

At the elementary level, simple acrobatic exercises are taught. Stretching, squatting, rolling exercises, these exercises can be performed on the waist, lying on your back, knees, and squats. In the next stage, the participants will be taught the exercises of forward squats, chips, and standing on shovels. In the third stage, it is recommended for participants to perform a set of exercises from the above, to build a bridge to the back 2-3 times, to jump back under the shoulders, to train the back to rise.

\section{REFERENCES}

1. Umarov M.N. Gymnastics. -T. Vneshinvestprom, 2015. - 156 p.

2. Eshtaev A.K. Gymnastics lesson. - Tashkent. UzDJTI, 2004. - 253 p.

3. Umarov M.N, Eshtayev AK, Ishtayev D.R, Toy'chiyev Z.O'., Eshtayev S.A, Pakhrudinova N.Yu. Theory and methodology of gymnastics. - T .: Barkamol fayz media, 2017. - $242 \mathrm{p}$.

4. Abdullaeva B.P. Corruption in the field of education: assessments and ways to address. "Тенденции и перспективи развития науки и образования в условиях

глобализации".Международной научнопрактической интернет-конференции. г.Переяслав, Украина.2020 год 30

5. Abdullaeva B.P. Babaraximova B.P. Pardaev B.P.Using information and communication technologies in teaching process of various primary European Journal of Research and Reflection in Educational Sciences, 8 (10), 67-70. Progressive Academic Publishing, UKwww.idpublications.org 14.10.2020.

6. Abdullaeva B.P. Abdullaev F.T. Organization of Swimming Lessons In Preschool Institutions THE AMERICAN JOURNAL OF SOCIAL SCIENCE AND EDUCATION INNOVATIONS. JULY 2020[ TAJSSEI]322ISSN (e):2689-100X DOI: https://doi.org/10.37547/tajssei/Volume0 2Issue 07-423.

7. Abdullayeva, B.P., \& Babaraximova, B. P. (2020). MAKTABGACHA TA'LIM MUASSASASIDA FUTBOL DARSLARINI TASHKIL ETISH METODIKASI. Academic Research in Educational Sciences http://ares.uz/jurnallar-sahifasi/ares-vol1-no-3-2020.

8. Abdullaeva B.P. ACADEMICIA: An 
CURRENT RESEARCH JOURNAL OF PEDAGOGICS 2(8): 101-109, August

2021 DOI: https://doi.org/10.37547/pedagogics-crjp-02-08-23

ISSN 2767-3278

(C)2021 Master Journals

Crossref dof 81 Google

Accepted 26 $6^{\text {th }}$ August, 2021 \& Published 31 ${ }^{\text {th }}$ August, 2021

International Multidisciplinary Research Journal https://saarj.com ORGANIZATION AND METHODOLOGY OF CONDUCTING FOOTBALL LESSONS IN A PRESCHOOL INSTITUTION 650-655 10.5958/22497137.2021.00098.

9. Abdullaeva B.P. Teaching A Child To Play Football From A Youth. The American Journal of Interdisciplinary Innovations and Research (ISSN-2642-7478) Published: April 30, 2021. Pages:147-151 Doi:https://doi.org/10.37547/tajiir/Volum e03Issue04-24MPACT

FACTOR2021:5.6760CLC-1091588944. 